\title{
Mass Oviposition and Egg Development of the Ocean-Skater Halobates sobrinus (Heteroptera: Gerridae) ${ }^{1}$
}

\author{
Lanna Cheng ${ }^{2}$ and Robert L. Pitman ${ }^{3}$
}

\begin{abstract}
We report the first observation of mass oviposition by the oceanskater Halobates sobrinus White in the eastern tropical Pacific Ocean. We netted, in one scoop, 833 insects and a single egg mass with an estimated 70,000 eggs on a plastic gallon (3.785-liter) milk jug. Evidently anthropogenic debris could provide potentially important oviposition substrates for Halobates spp. in the open ocean. Freshly laid eggs incubated at $26-32^{\circ} \mathrm{C}$ hatched within $8-10$ days. Eggs kept at temperatures below $22^{\circ} \mathrm{C}$ did not hatch even after 20 days.
\end{abstract}

Pelagic species of the ocean-skater Halobates live all their lives at the sea surface. Unlike their coastal congeners, which lay eggs on rocks or roots and branches of mangroves or other plants (Cheng 1985, Foster and Treherne 1986), ocean-skaters must rely on flotsam as oviposition substrates, which include pieces of wood, cork, coal, pumice, plastic, tar, seeds, seaweed, empty mollusk shells (Spirula and Sepia), seabird feathers, and even dead or dying seabirds (Lundbeck 1914, Herring 1961, Cheng 1985, Andersen and Foster 1992). The most unusual oviposition substrates reported are shells of living heteropods (Atlanta spp.), which usually live some tens to a few hundred meters below the sea surface (Seapy 1996). Male atlantids that had come to the surface to swarm were presumably encountered by gravid Halobates females, which laid eggs on them. Most of these objects bore only several or a few dozen eggs, but one piece of cork and the tail feathers of a

1 This work was carried out during a 3-yr Stenella Abundance Research Survey funded by NOAA and conducted by the National Marine Fisheries Service. Manuscript accepted 28 January 2002.

${ }^{2}$ Scripps Institution of Oceanography, University of California at San Diego, 9500 Gilman Drive, La Jolla, California 92093-0202.

${ }^{3}$ Southwest Fisheries Science Center, National Marine Fisheries Service, National Oceanic and Atmospheric Administration, 8604 La Jolla Shores Drive, La Jolla, California 92037.

Pacific Science (2002), vol. 56, no. 4:441-445

(C) 2002 by University of Hawai'i Press

All rights reserved dead common noddy, Anous stolidus, were estimated to bear many thousand eggs (Andersen and Polhemus 1976). None of these eggs could be identified to species except by inference from their geographic location in relation to distribution ranges of particular Halobates species.

Although we know a lot about the ecology of Halobates (Cheng 1985), we still have no idea how these insects find potential mates or suitable oviposition substates in the open ocean. Certain freshwater gerrids are known to use surface ripples for attracting mates (Wilcox and Spence 1986), but this has not been demonstrated in any marine species. A calm water surface would seem to be a prerequisite for ripple communication to function, but such conditions are only sporadic in the open sea. In the Caribbean, males of a related coastal veliid, Trochopus plumbeus (Uhler) (Heteroptera: Veliidae), were shown to use surface-dispersible semiochemicals to attract females (Cheng and Roussis 1998). Similar chemical attractants may perhaps be employed by Halobates.

The distribution range of each of the five pelagic Halobates species is well defined and may cover several thousand square kilometers of tropical ocean surface (Cheng 1989). Theoretical calculations based on oceanic diffusion have shown that mutual encounter rates between individuals, due to ocean turbulence alone, could be as high as $11^{-\mathrm{d}}$ (Ikawa et al. 1998). Whether oceanic diffusion is sufficient to bring the sexes together or whether some other physical or chemical factors are involved has yet to be determined. 
This is the first report on mass oviposition, egg development, and a direct association between Halobates adults and an artificial oviposition substrate at the sea surface. The observations were carried out in the eastern tropical Pacific Ocean during two separate legs of a 3-yr survey (1998-2000) on marine mammals undertaken by the Southwest Fisheries Science Center in La Jolla, California.

\section{MATERIALS AND METHODS}

Oviposition and egg development were studied on board ship in October 1999 by L.C. Halobates females collected by dip net were allowed to lay eggs on moistened filter paper. Pieces of paper bearing about 20 eggs in total were placed in five separate covered containers, immersed in seawater, and kept as follows: $26-32^{\circ} \mathrm{C}$ (on ship deck), $28-30^{\circ} \mathrm{C}$ (ocean laboratory), $18-22^{\circ} \mathrm{C}$ (instrument laboratory), $10-15^{\circ} \mathrm{C}$ (cold-room), and $4-5^{\circ} \mathrm{C}$ (refrigerator). Egg development was observed daily until the eggs hatched, or at the conclusion of the expedition 20 days later.

On 31 October 2000, a plastic gallon (3.785-liter) milk jug was sighted by R.L.P., floating on the open ocean about $600 \mathrm{~km}$ off the coast of Mexico. As the ship passed within $50 \mathrm{~m}$ of the jug we could see that its surface was rendered almost black by a swarm of Halobates. As we circled and approached more closely, most of the insects skated away, but by using a long-handled dip net we succeeded in scooping up the jug and catching about $20 \%$ of the insects. The jug was found to be almost completely covered by eggs, which we scraped off and preserved in 95\% ethanol, together with the insects, for subsequent examination in the laboratory. No fish, crabs, or other animals were found associated with the jug. Ten Halobates females were dissected to determine egg numbers in their oviducts.

Data on relative population densities and species composition of Halobates and other surface organisms were obtained from samples collected during the expedition by two operators using long-handled dip nets. We used two $500-W$ lamps suspended over the side of the ship at night to attract and illuminate the animals. Each net had an opening 75 $\mathrm{cm}$ in diameter, with a depth of $100 \mathrm{~cm}$, and was mounted on a wooden handle $8 \mathrm{~m}$ long. We sampled for $1 \mathrm{hr}$ each night, after sunset, while the ship was at station. Samples collected were then sorted into major animal taxa and preserved in $70 \%$ ethanol in separate vials. Halobates collected were counted, identified to species, and separated into adults by sexes, and development stages.

\section{RESULTS AND OBSERVATIONS}

When provided with moistened filter papers, female Halobates sobrinus were observed to lay eggs in rapid succession (1 to $2 \mathrm{sec}^{-1}$ ) in batches of various numbers $(1,1,3,3,3,4,6$, $8,8,8,9,10,11,13,29)$. The eggs were glued firmly to the substrate, and most, if not all, of the eggs laid by a single female were oriented in the same direction. Newly laid eggs were translucent and creamy white or pale olive green. They turned orange by the third day and reddish orange by the fifth day. Bright red eyespots and dark brown outlines of developing appendages became clearly visible on day 5 .

Temperature was found to be important in controlling rate of egg development. Eggs kept on deck and in the ocean laboratory (26$32^{\circ} \mathrm{C}$ ) hatched in 8 to 10 days. None of the eggs kept at lower temperatures (below $24^{\circ} \mathrm{C}$ ) hatched even after 20 days, when the experiment was terminated at the end of the cruise leg.

We caught 833 insects in association with the plastic jug. They were all identified as adults of a single species, Halobates sobrinus White. Females were somewhat more abundant $(62 \%)$ than males. About $6 \%$ of the females had just mated, as indicated by the slightly parted halves of the gonocoxa (ventrite of first genital segment). In nonmated females the two halves are closely appressed.

The rectangular egg mass scraped from the jug measured about 4 by $6 \mathrm{~cm}$. The eggs had been laid in a random fashion, without any obvious orientation, and were glued to the jug or to one another. They were oval, resembling miniature rice grains, and measured about $0.8 \mathrm{~mm}$ long by $0.4 \mathrm{~mm}$ wide. The total egg mass, some 15 egg layers thick, 
TABLE 1

Halobates Species, Total Number of Adults and Nymphs, and Location of Dip Net Samples Taken during a 3-day Period within a 500-km Radius of the Egg-Bearing Gallon Jug (Sample no. 0)

\begin{tabular}{|c|c|c|c|c|c|c|c|}
\hline Date 2000 & $\begin{array}{c}\text { Sample } \\
\text { No. }\end{array}$ & $\begin{array}{l}\text { Halobates } \\
\text { Species }\end{array}$ & $\begin{array}{l}\text { Total } \\
\text { Insects }\end{array}$ & $\begin{array}{l}\text { Total } \\
\text { Adults }\end{array}$ & $\begin{array}{c}\text { Total } \\
\text { Nymphs }\end{array}$ & $\begin{array}{c}\text { Latitude } \\
{ }^{\circ} \mathrm{N}\end{array}$ & $\begin{array}{c}\text { Longitude } \\
{ }^{\circ} \mathrm{W}\end{array}$ \\
\hline $\begin{array}{l}31 \text { Oct. } \\
\text { (Jug site) }\end{array}$ & 0 & sobrinus & 833 & 833 & 0 & $10^{\circ} 08^{\prime}$ & $94^{\circ} 56^{\prime}$ \\
\hline 30 Oct. & 1 & sobrinus & 194 & 165 & 29 & $12^{\circ} 47^{\prime}$ & $92^{\circ} 12^{\prime}$ \\
\hline 30 Oct. & 2 & $\begin{array}{l}\text { sobrinus } \\
\text { micans }\end{array}$ & $\begin{array}{r}124 \\
12\end{array}$ & $\begin{array}{r}117 \\
12\end{array}$ & $\begin{array}{l}7 \\
0\end{array}$ & $11^{\circ} 29^{\prime}$ & $93^{\circ} 33^{\prime}$ \\
\hline 31 Oct. & 3 & $\begin{array}{l}\text { sobrinus } \\
\text { micans }\end{array}$ & $\begin{array}{r}109 \\
3\end{array}$ & $\begin{array}{r}97 \\
3\end{array}$ & $\begin{array}{r}22 \\
0\end{array}$ & $10^{\circ} 40^{\prime}$ & $94^{\circ} 25^{\prime}$ \\
\hline 31 Oct. & 4 & sobrinus & 134 & 123 & 11 & $09^{\circ} 47^{\prime}$ & $95^{\circ} 43^{\prime}$ \\
\hline 01 Nov. & 5 & $\begin{array}{l}\text { sobrinus } \\
\text { micans }\end{array}$ & $\begin{array}{r}56 \\
1\end{array}$ & $\begin{array}{r}53 \\
1\end{array}$ & $\begin{array}{l}2 \\
0\end{array}$ & $09^{\circ} 00^{\prime}$ & $94^{\circ} 56^{\prime}$ \\
\hline 01 Nov. & 6 & $\begin{array}{l}\text { sobrinus } \\
\text { micans }\end{array}$ & $\begin{array}{l}3 \\
4\end{array}$ & $\begin{array}{l}3 \\
4\end{array}$ & $\begin{array}{l}0 \\
0\end{array}$ & $07^{\circ} 58^{\prime}$ & $97^{\circ} 34^{\prime}$ \\
\hline
\end{tabular}

was estimated to contain about 70,000 eggs. The eggs were all creamy white and judged to be at about the same developmental stage, no more than 3 days old. Of the 10 females collected with the jug that we dissected, 1 carried no eggs, and the other 9 contained from 6 to 20 eggs $(6,6,8,9,10,12,12,16,20)$, with an average of 10 per female. We estimate that the jug must have been used by at least 7000 females.

Results of Halobates samples collected during a 3 -day period and within a $500-\mathrm{km}$ radius of the jug sighting are presented in Table 1. Two species were collected and identified: $H$. sobrinus and $H$. micans. Although both species co-occurred in four of the six samples collected, $H$. sobrinus was obviously the dominant species responsible for laying the eggs reported here.

During the entire 3-yr expedition (19982000) we collected only about 20 other items of floating debris (none exceeded 3 by $4 \mathrm{~cm}$ ) with 2-30 Halobates eggs attached: pieces of styrofoam, plastic, mollusk shells, twigs, and feathers of seabirds. We also found a freshly dead brown booby (Sula leucogaster) with several hundred eggs attached to the tail feathers.

\section{DISCUSSION}

Egg development in Halobates sobrinus is evidently temperature dependent. All eggs kept above $25^{\circ} \mathrm{C}$ hatched within 10 days, but those kept below $22^{\circ} \mathrm{C}$ did not hatch even after 20 days. We were unable to determine whether eggs kept at lower temperatures would remain viable or eventually hatch because the experiment had to be terminated. In its natural habitat, $H$. sobrinus is found only in waters above $20^{\circ} \mathrm{C}$ and is abundant in areas where seawater temperatures range between 24 and $28^{\circ} \mathrm{C}$ (Cheng and Shulenberger 1980). We do not know how many eggs an adult female can produce in her lifetime. Halobates adults have been kept alive in the laboratory for over a month and may live for 2 months or more in their natural habitat (Cheng 1985). Although females have laid an average of only 10 eggs per session in our study, they can carry up to 30 eggs or more in their oviducts (Cheng 1985). It is likely that they can mature eggs in batches as needed or when food becomes available (Cheng and Frank 1993). Halobates appears to have adopted a strategy of slow growth and prolonged longevity to survive at the ocean surface (Ikawa et al. 1998).

Ocean-skaters have well-developed eyes and in daylight presumably locate their prey as well as mates and oviposition substrates by sight. However, because they are confined to a two-dimensional, featureless habitat at the sea-air interface, with their bodies raised only about $1 \mathrm{~mm}$ or so above the sea surface, it seems that it would be difficult for them to see potential mates amid ocean waves except 
when the sea is calm. A relatively large floating object, such as a gallon jug, could presumably be more easily seen from many meters away and could thus possibly serve as a "beacon" to guide wandering Halobates to aggregate, mate, and lay eggs. The fact that in one scoop we netted 833 insects (which we estimated to represent only $20 \%$ of the insects originally present) along with the jug suggests that the insects had been somehow attracted to the jug. In contrast, our dip net samples taken nearby on the same day yielded only 97 adult $H$. sobrinus in $2 \mathrm{hr}$ of sampling (Table 1 , sample 3 ). It is possible that females can retain mature eggs until suitable substrates or favorable environmental conditions for egg development are encountered. If the gallon jug was the only suitable substrate available, it would, out of necessity, be used by all gravid females in the surrounding area.

Whether there are potential evolutionary benefits or adaptive advantages for mass oviposition is unclear. Although aggregation of adults may help to improve their chances of finding a suitable mate, it may also facilitate their detection and predation by seabirds, which are the main predators of Halobates (Cheng and Harrison 1983). On the other hand, when a dense flotilla of the coastal species Halobates robustus (endemic to the Galápagos Islands) was approached by seabirds, agitated and accelerated activities of individuals were seen to confuse the predators, causing them to lose the prey (Treherne and Foster 1981). Such "schooling" or herding behavior for reducing predation pressure is well known for many organisms, including even an aquatic plant (Moore 2001). Thus mass oviposition and more-or-less synchronized hatching of eggs may increase the chances of survival of young Halobates nymphs.

Although $H$. sobrinus and $H$. micans cooccur in the eastern tropical Pacific Ocean, they may not share the same ecological niche, because the areas where each occurs in abundance are almost completely separate (Cheng and Shulenberger 1980). Specimens of both species were collected by dip net in the vicinity of the jug (Table 1), but adults of $H$. micans were found in rather low numbers (1-
12) compared with $H$. sobrinus (up to 194), which was the only species associated with the egg-bearing jug. It is evident that $H$. sobrinus was very abundant in this area. The highest population density for this species reported in the eastern tropical Pacific was $10,000 \mathrm{~km}^{-2}$ (Cheng and Shulenberger 1980).

We do not know whether a mass oviposition on the scale we observed is exceptional. On the same day, within $10 \mathrm{~km}$ of the jug sighting, we passed another floating object of similar size, surrounded by another dark swarm of Halobates, but we were unable to stop the ship to sample it. During our 3-yr study period in the eastern tropical Pacific, we often saw large pieces of debris, but we never observed breeding swarms of Halobates associated with them. Although we collected Halobates at over $90 \%$ of all stations (150-200 per year) during our 3-yr survey in the eastern tropical Pacific, we found less than 20 pieces of egg-bearing flotsam, suggesting that there may be a shortage of suitable oviposition substrates in the open ocean. The fact that the gallon jug had been used by no less than 7000 females indicates that suitable substrates may indeed be rare and may be limiting Halobates reproduction. Thus, input of anthropogenic debris might promote increases in population of these enigmatic ocean insects.

\section{ACKNOWLEDGMENTS}

We are most grateful to the captain and crew of the NOAA Research Ships McArtbur and David Starr Fordan, and to our fellow shipmates, for their help in various ways in facilitating our research.

\section{Literature Cited}

Andersen, N. M., and W. A. Foster. 1992. Sea skaters of India, Sri Lanka, and the Maldives, with a new species and a revised key to Indian Ocean species of Halobates and Asclepios (Hemiptera, Gerridae). J. Nat. Hist. 26:533-553.

Andersen, N. M., and J. T. Polhemus. 1976. Water-striders (Hemiptera: Gerridae, Veliidae, etc.). Pages 187-224 in L. Cheng, 
ed. Marine insects. American Elsevier, New York.

Cheng, L. 1985. Biology of Halobates (Heteroptera: Gerridae). Annu. Rev. Entomol. 30:111-135.

1989. Factors limiting the distribution of Halobates species. Pages 357-362 in J. S. Ryland and P. A. Tyler, eds. Reproduction genetics and distributions of marine organisms. Olsen and Olsen, Fredenborg, Denmark.

Cheng, L., and J. H. Frank. 1993. Marine insects and their reproduction. Oceanogr. Mar. Biol. Annu. Rev. 31:479-506.

Cheng, L., and C. S. Harrison. 1983. Seabird predation on the sea-skater Halobates sericeus (Heteroptera: Gerridae). Mar. Biol. (Berl.) 72:303-309.

Cheng, L., and V. Roussis. 1998. Sex attractant in the marine insect Trochopus plumbeus (Heteroptera: Veliidae): A preliminary report. Mar. Ecol. Prog. Ser. 170:283-286.

Cheng, L., and E. Shulenberger. 1980. Distribution and abundance of Halobates species (Insects: Heteroptera) in the eastern tropical Pacific. Fish. Bull. 78:579-591.

Foster, W. A., and J. E. Treherne. 1986. The ecology and behaviour of a marine insect, Halobates fijiensis (Hemiptera: Gerridae). Zool. J. Linn. Soc. 86:391-412.

Herring, J. L. 1961. The genus Halobates. Pac. Insects 3:223-305.

Ikawa, T., A. Okubo, H. Okabe, and L. Cheng. 1998. Oceanic diffusion and the pelagic insects Halobates spp. (Gerridae: Hemiptera). Mar. Biol. (Berl.) 131:95-201.

Lundbeck, W. 1914. Some remarks on the eggs and egg-deposition of Halobates. Mindeskrift für Japetus Steenstrup 2:1-13. Moore, P. D. 2001. Crowd trouble for predators. Nature (Lond.) 413:265.

Seapy, R. R. 1996. Atlantid heteropods as living substrata for eggs of Halobates sericeus (Heteroptera: Gerridae). Pac. Sci. 50:84-92.

Treherne, J. E., and W. A. Foster. 1981. Group transmission of predator avoidance behaviour in a marine insect: The Trafalgar effect. Anim. Behav. 29:911-917.

Wilcox, R. S., and J. R. Spence. 1986. The mating system of two hybridizing species of water striders (Gerridae). I. Ripple signal functions. Behav. Ecol. Sociobiol. 19:79-85. 